\title{
Total synthesis of decarboxyaltenusin
}

\author{
Lucas Warmuth ${ }^{1}$, Aaron Weiß ${ }^{1}$, Marco Reinhardt ${ }^{1}$, Anna Meschkov², Ute Schepers ${ }^{2}$ \\ and Joachim Podlech*1
}

\author{
Full Research Paper \\ Address: \\ ${ }^{1}$ Institute of Organic Chemistry, Karlsruhe Institute of Technology \\ (KIT), 76131 Karlsruhe, Fritz-Haber-Weg 6, Germany and ${ }^{2}$ Institute of \\ Toxicology and Genetics, Karlsruhe Institute of Technology (KIT), \\ 76344 Eggenstein-Leopoldshafen, Hermann-von-Helmholtz-Platz 1, \\ Germany \\ Email: \\ Joachim Podlech ${ }^{*}$ - joachim.podlech@kit.edu \\ * Corresponding author \\ Keywords: \\ biaryls; boronates; mycotoxins; polyketides; Suzuki coupling
}

\author{
Beilstein J. Org. Chem. 2021, 17, 224-228. \\ https://doi.org/10.3762/bjoc.17.22 \\ Received: 24 November 2020 \\ Accepted: 13 January 2021 \\ Published: 22 January 2021 \\ Associate Editor: K. Grela \\ (C) 2021 Warmuth et al.; licensee Beilstein-Institut. \\ License and terms: see end of document.
}

\begin{abstract}
The total synthesis of decarboxyaltenusin (5'-methoxy-6-methyl-[1,1'-biphenyl]-3,3',4-triol), a toxin produced by various mold fungi, has been achieved in seven steps in a yield of 31\% starting from 4-methylcatechol and 1-bromo-3,5-dimethoxybenzene, where the longest linear sequence consists of five steps. The key reaction was a palladium-catalyzed Suzuki coupling of an aromatic boronate with a brominated resorcin derivative.
\end{abstract}

\section{Introduction}

5'-Methoxy-6-methyl-[1,1'-biphenyl]-3,3',4-triol (1, Scheme 1) has been first mentioned 1974 as a reduction and decarboxylation product of dehydroaltenusin [1]. As the compound has later been isolated from Ulocladium sp. [2], Nigrospora sphaerica, Phialophora sp. [3], Penicillium pinophilum SD-272 [4], Alternaria sp. [3,5,6], and from the endophytic fungus Botryosphaeria dothidea in Melia azedarach [7] it turned out to be a widely occurring natural product. It shows marked DPPH radical scavenging activities with determined $\mathrm{IC}_{50}$ values of $18.7 \pm 0.2 \mu \mathrm{M}$ [7] and $148 \pm 3 \mu \mathrm{M}$ [2], respectively, and displays inhibitory activity against three tyrosine kinases (EGFR, VEGFR-1, and c-Met) [5]. As mentioned, it is accessible through the reduction of dehydroaltenusin with zinc powder in acetic acid with intermediate formation of altenusin
[1]. Nevertheless, this route cannot be considered as a viable approach to this compound due to the reduced accessibility of the precursors and since no experimental details have been published for the transformation. To continue our efforts in the total synthesis of mycotoxins [8-18] and to provide larger amounts of the polyketide 1 sufficient for thorough biological investigations (as have been suggested by the European Food Safety Authority, EFSA [19]), we considered it useful to supply a more straightforward synthesis of this compound, for which we here propose the obvious name decarboxyaltenusin.

\section{Results and Discussion}

In a retrosynthetic analysis, we envisioned a Suzuki coupling of two suitably substituted arenes. Silyl protecting groups like the 
<smiles>COc1cc(O)cc(-c2cc(O)c(O)cc2C)c1</smiles>

decarboxyaltenusin dehydroaltenusin<smiles>COc1cc(O)c(C(=O)O)c(-c2cc(O)c(O)cc2C)c1</smiles>

altenusin

Scheme 1: Biphenyl-derived mycotoxins.

tert-butyldimethylsilyl group (TBS) were considered appropriate for all projected reaction steps. The boronate moiety $\mathbf{6 a}$ was prepared starting with 4-methylcatechol (2), which was initially protected with tert-butyldimethylsilyl chloride in the presence of 4-(dimethylamino)pyridine (DMAP) and imidazole (Scheme 2) according to a published procedure [20]. The thus obtained bis(silylether) $\mathbf{3}$ was then brominated with $\mathrm{N}$-bromosuccinimide (NBS), where the utilization of acetonitrile as solvent [21] instead of carbon tetrachloride [22] furnished a close to quantitative yield of bromide $\mathbf{5 a}$, though a prolonged reaction time of $72 \mathrm{~h}$ had to be accepted. The subsequent formation of boronate 6a was accomplished through a metal-halogen interchange with butyllithium and trapping with 2-isopropoxy4,4,5,5-tetramethyl-1,3,2-dioxaborolane [23].

The electrophilic compound suitable for the projected cross coupling was obtained by mono-demethylation of commercially available 1-bromo-3,5-dimethoxybenzene (7) with boron tribromide (Scheme 3). A satisfactory yield of phenol 8 was observed with 0.9 equivalents of the Lewis acid, while the utilization of 1.5 equivalents led to a significant overreaction with the predominant formation of 5-bromobenzene-1,3-diol (59\%) together with a smaller amount of the required product $8(30 \%)$. The subsequent protection with the TBS group yielded the known aryl bromide 9a [24] with a 73\% yield.

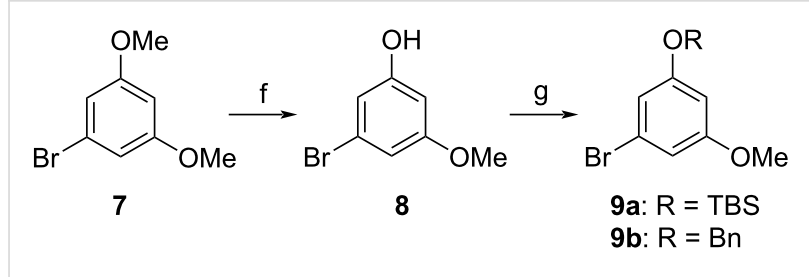

Scheme 3: Synthesis of aryl bromides 9. Conditions: f) $\mathrm{BBr}_{3},-78{ }^{\circ} \mathrm{C}$ to rt, $18 \mathrm{~h}(71 \%)$; g) $\mathrm{R}=\mathrm{TBS}$ : TBSCl, DMAP, imidazole, DMF, $55^{\circ} \mathrm{C}$, $4 \mathrm{~h}(73 \%) ; \mathrm{R}=\mathrm{Bn}: \mathrm{BnBr}, \mathrm{K}_{2} \mathrm{CO}_{3}, \mathrm{DMF} /$ acetone $1: 2,80^{\circ} \mathrm{C}, 43 \mathrm{~h}$ $(98 \%)$.

The Suzuki coupling of boronate $\mathbf{6 a}$ and aryl bromide 9a using palladium acetate and cesium carbonate in the presence of the ligand SPhos [25] yielded biaryl 10a with virtually quantitative yield (98\%, Scheme 4). Unfortunately, the removal of nonidentified byproducts and of 9a (which had been used in a 1.2-fold excess) turned out to be very laborious. Moreover, the subsequent deprotection to the natural product $\mathbf{1}$ could not be achieved sufficiently: After treatment of 10a with tetrabutylammonium fluoride (TBAF), the signals of $\mathbf{1}$ could be detected in a ${ }^{1} \mathrm{H}$ NMR spectrum of the crude product, but purification and isolation of the product by column chromatography was not possible - neither with conventional nor with reversed phase methods. It turned out that the high polarity of the triol complicated its separation from other polar side products.

To circumvent this problem, we decided to use a different protection group strategy and to employ hydrogenolytically cleavable benzyl groups. The synthesis of the benzyl-protected boronate was here achieved with a modified strategy including bromination [21] of 4-methylcatechol (2) to the known bromide 4 [26] and subsequent benzyl protection to the bis(benzyl ether) $\mathbf{5 b}$ using standard conditions (Scheme 2) [27]. The preparation of boronate $\mathbf{6 b}$ applying the conditions used for the silylated substrate $\mathbf{6 a}$ (vide supra) led to a mediocre $44 \%$ yield, but

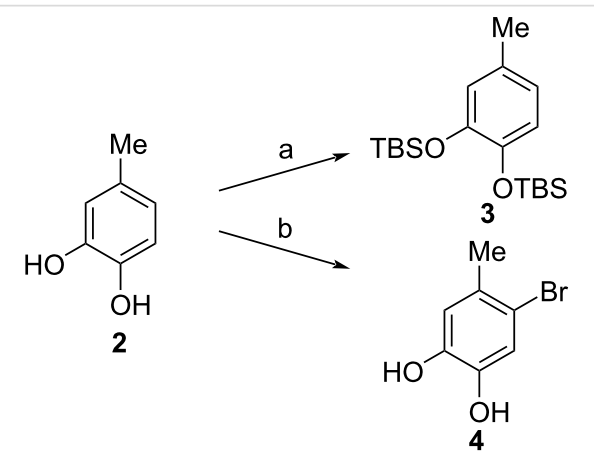<smiles>C1CCCCC1</smiles><smiles>[O]c1cc([18O])c([N+](=O)[O-])cc1[18O]</smiles>

5a: $R=T B S$ 5b: $\mathrm{R}=\mathrm{Bn}$<smiles>[R20]Oc1cc(B2OC(C)(C)C(C)(C)O2)c([N+](=O)[O-])cc1[R]</smiles>

6a: $R=T B S$ 6b: $R=B n$

Scheme 2: Synthesis of arylboronates 6. Conditions: a) TBSCI, DMAP, imidazole, DMF, $50{ }^{\circ} \mathrm{C}, 4 \mathrm{~h}(96 \%)$; b) NBS, MeCN, rt, $71 \mathrm{~h}(\mathrm{quant}$ ); c) NBS, $\mathrm{MeCN}, \mathrm{rt}, 72 \mathrm{~h}(\mathrm{R}=\mathrm{TBS}, 96 \%)$; d) $\mathrm{BnBr}, \mathrm{KI}, \mathrm{K}_{2} \mathrm{CO}_{3}$, DMF/acetone, $70{ }^{\circ} \mathrm{C}, 29 \mathrm{~h},(\mathrm{R}=\mathrm{Bn}, 86 \%)$; e) $\mathrm{R}=\mathrm{TBS}$ : BuLi, 2-isopropoxy-4,4,5,5-tetramethyl1,3,2-dioxaborolane, THF, $-78^{\circ} \mathrm{C}, 0.45-2 \mathrm{~h}, \mathrm{rt}, 18 \mathrm{~h}(57 \%) ; \mathrm{R}=\mathrm{Bn}$ : bis(pinacolato)diboron, $\mathrm{Pd}(\mathrm{dppf}) \mathrm{Cl}_{2} \cdot \mathrm{CH}_{2} \mathrm{Cl}_{2}\left(\mathrm{cat}_{\text {. }}\right), \mathrm{KOAc}$ dioxane, $80{ }^{\circ} \mathrm{C}, 17 \mathrm{~h}$ $(55 \%)$. 


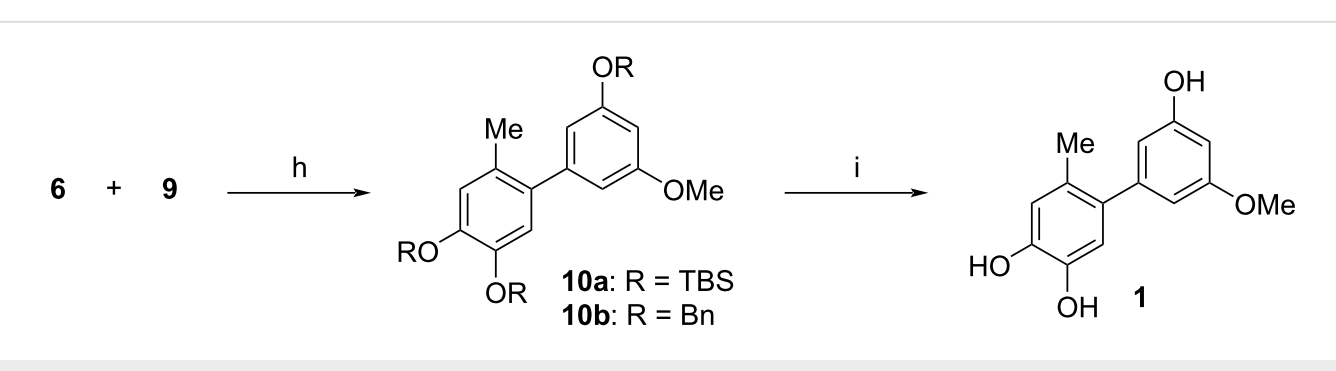

Scheme 4: Final steps in the synthesis of biaryl 1. Conditions: h) $\mathrm{Pd}(\mathrm{OAc})_{2}$, SPhos, $\mathrm{Cs}_{2} \mathrm{CO}_{3}$, dioxane/ $\mathrm{H}_{2} \mathrm{O} 7: 1,70{ }^{\circ} \mathrm{C}, 18 \mathrm{~h},(\mathrm{R}=\mathrm{TBS}: 98 \%$, containing non-separable impurities; $\mathrm{R}=\mathrm{Bn}: 89 \%)$; i) $\mathrm{R}=\mathrm{Bn}$ : $\mathrm{Pd} / \mathrm{C}(10 \%), \mathrm{H}_{2}, \mathrm{THF}, 8 \mathrm{bar}, 24 \mathrm{~h}, 40{ }^{\circ} \mathrm{C}(88 \%)$.

the utilization of a palladium-catalyzed borylation with bis(pinacolato)diboron afforded the product with 55\% yield. The $O$-benzylation of phenol $\mathbf{8}$ furnishing the bromide $\mathbf{9 b}$ was accomplished with virtually quantitative yield. Suzuki coupling of the benzyl-protected compounds $6 \mathbf{b}$ and $9 \mathrm{~b}$ led to biaryl 10b with $89 \%$ yield; it was deprotected with palladium on charcoal under eight bar hydrogen pressure (Scheme 4 ). The product 1 could now be purified by a simple chromatography on silica gel and was obtained in $88 \%$ yield.

NMR spectroscopic data of the natural product had been published by Wang et al. [2] and by Xiao et al. [7] (Table 1). A comparison of the ${ }^{13} \mathrm{C}$ NMR data of the now synthesized compound with Wang's data shows a systematic deviation of about

\begin{tabular}{|c|c|c|c|c|}
\hline \multicolumn{2}{|l|}{ natural product } & \multicolumn{2}{|c|}{ synthetic product } & \multirow{2}{*}{$\begin{array}{l}\text { deviation }^{a} \\
\Delta \delta[p p m]\end{array}$} \\
\hline$\delta[\mathrm{ppm}]^{\mathrm{b}, \mathrm{c}}$ & $\delta[p p m]^{\mathrm{c}, \mathrm{d}}$ & signal & $\delta$ [ppm] & \\
\hline 19.8 & 19.50 & 6-Me & 19.4 & $-0.4 /-0.1$ \\
\hline 55.4 & 54.97 & OMe & 54.9 & $-0.5 /-0.1$ \\
\hline 99.7 & 99.21 & C-4' & 99.2 & $-0.5 / \pm 0.0$ \\
\hline 106.2 & 105.80 & C-2' & 105.8 & $-0.4 / \pm 0.0$ \\
\hline 109.3 & 108.84 & C-6' & 108.8 & $-0.5 / \pm 0.0$ \\
\hline 117.1 & 116.70 & C-2 & 116.7 & $-0.4 / \pm 0.0$ \\
\hline 118.0 & 117.56 & $C-5$ & 117.5 & $-0.5 /-0.1$ \\
\hline 125.3 & 124.89 & C-6 & 124.8 & $-0.5 /-0.1$ \\
\hline 132.7 & 132.30 & C-1 & 132.3 & $-0.4 / \pm 0.0$ \\
\hline $143.5^{e, f}$ & 142.92 & C-1' & 142.9 & $-0.6 / \pm 0.0$ \\
\hline $144.5^{e, f}$ & 143.66 & C-3 & 143.6 & $-0.9 /-0.1$ \\
\hline $144.8^{e, f}$ & 144.39 & C-4 & 144.3 & $-0.5 /-0.1$ \\
\hline 158.5 & 158.06 & C-3' & 158.0 & $-0.5 /-0.1$ \\
\hline 160.4 & 160.04 & C-5 & 160.0 & $-0.4 / \pm 0.0$ \\
\hline $2.05(\mathrm{~s})$ & & $6-\mathrm{CH}_{3}$ & $2.05(\mathrm{~s})$ & \pm 0.00 \\
\hline $3.69(\mathrm{~s})$ & & $5^{\prime}-\mathrm{OCH}_{3}$ & $3.70(\mathrm{~s})$ & +0.01 \\
\hline 6.20 (br. s) & & 6'-H & $6.20(\mathrm{dd})$ & \pm 0.00 \\
\hline 6.21 (br. s) & & 2'-H & $6.22(\mathrm{t})$ & +0.01 \\
\hline 6.25 (br. s) & & $4^{\prime}-\mathrm{H}$ & $6.25(t)$ & \pm 0.00 \\
\hline $6.54(\mathrm{~s})$ & & $2-\mathrm{H}$ & $6.55(\mathrm{~s})$ & +0.01 \\
\hline $6.60(\mathrm{~s})$ & & $5-\mathrm{H}$ & $6.60(\mathrm{~s})$ & \pm 0.00 \\
\hline 8.72 (br. s) & & $3-\mathrm{OH}$ & 8.72 (br. s) & \pm 0.00 \\
\hline 8.78 (br. s) & & $4-\mathrm{OH}$ & 8.78 (br. s) & \pm 0.00 \\
\hline 9.42 (br. s) & & 3'-OH & 9.37 (br. s) & -0.05 \\
\hline
\end{tabular}

aDeviation of the synthesized product's data from published data: Wang et al. [2]/Xiao et al. [7]; bdata published by Wang et al. [2]; cthe data are given in ascending order. Assignments in the original papers are in agreement with those given for the synthesized product (except footnote e); ${ }^{d}$ data published by Xiao et al. [7]; 'the assignment in the original paper is: 143.5: C-4, 144.5: C-3, and 144.8: C-1'; 'a superscript letter is included after these numbers in the original paper, but a corresponding footnote is missing. It can be assumed that the assignment of these signals had been considered questionable. 
$-0.5 \mathrm{ppm}$ (possibly due to a calibration inaccuracy in the original paper) and a deviant signal around $144 \mathrm{ppm}$, which is a further -0.4 ppm off (marked in boldface). Nevertheless, all signals published by Xiao et al. are in virtually perfect agreement with the NMR data measured by us, what leaves no reasonable doubt that the synthesized structure $\mathbf{1}$ is identical with the natural product.

Decarboxyaltenusin (1) was screened for toxicity towards human HeLa cells but proved nontoxic at biologically relevant concentrations and showed an $\mathrm{LD}_{50}$ value of above $50 \mu \mathrm{M}$. This screening was performed by measuring the cell viability using an MTT assay, where the viability is assessed based upon the reduction of the yellow tetrazolium MTT [3-(4,5-dimethylthiazolyl-2)-2,5-diphenyltetrazolium bromide] by metabolically active and hence viable cells. The resulting intracellular purple formazan was quantified spectrophotometrically. The cell viability was calculated based on an untreated control. The cell viability cut-off was $<70 \%$. At a $0.5 \mu \mathrm{M}$ concentration of decarboxyaltenusin (1), it was $103 \% \pm 1 \%$, at $5 \mu \mathrm{M}$ it was $94 \% \pm 1.4 \%$, and at $50 \mu \mathrm{M} 92 \% \pm 1 \%$.

\section{Conclusion}

The total synthesis of decarboxyaltenusin (1) was achieved in seven steps in a yield of $31 \%$ starting from 4-methylcatechol (2) and 1-bromo-3,5-dimethoxybenzene (7), where the longest linear sequence has consisted of five steps. Decarboxyaltenusin turned out to be nontoxic towards human HeLa cells.

\section{Supporting Information}

\section{Supporting Information File 1}

Experimental procedures and NMR spectra of all new compounds and of decarboxyaltenusin (1).

[https://www.beilstein-journals.org/bjoc/content/ supplementary/1860-5397-17-22-S1.pdf]

\section{Acknowledgements}

We are deeply indebted to Dr. Nicole Jung and Dr. Anke Deckers from Compound Platform (ComPlat).

\section{Funding}

The work was supported by the Helmholtz Program Biointerfaces in Technology and Medicine (BIFTM).

\section{ORCID ${ }^{\circledR}$ iDs}

Lucas Warmuth - https://orcid.org/0000-0002-2234-028X Aaron Weiß - https://orcid.org/0000-0002-1638-2002 Marco Reinhardt - https://orcid.org/0000-0002-6401-719X
Ute Schepers - https://orcid.org/0000-0002-2736-6200 Joachim Podlech - https://orcid.org/0000-0001-7881-6905

\section{References}

1. Kameda, K.; Aoki, H.; Namiki, M.; Overeem, J. C. Tetrahedron Lett 1974, 15, 103-106. doi:10.1016/s0040-4039(01)82147-x

2. Wang, Q.-X.; Bao, L.; Yang, X.-L.; Guo, H.; Yang, R.-N.; Ren, B.; Zhang, L.-X.; Dai, H.-Q.; Guo, L.-D.; Liu, H.-W. Fitoterapia 2012, 83, 209-214. doi:10.1016/j.fitote.2011.10.013

3. He, J.-W.; Chen, G.-D.; Gao, H.; Yang, F.; Li, X.-X.; Peng, T.; Guo, L.-D.; Yao, X.-S. Fitoterapia 2012, 83, 1087-1091. doi:10.1016/j.fitote.2012.05.002

4. Wang, M.; Li, X.; Li, C.; Wang, B. Haiyang Kexue 2014, 38, 1-5. doi:10.11759/hykx20130323002 Chem. Abstr. 2015, 162, 652122.

5. Guo, L.-z.; Liu, C.-x.; Xu, B.; Chen, J.-f.; Zou, K.; Guo, Z.-y. Huaxue Yanjiu Yu Yingyong 2014, 26, 306-310. Chem. Abstr. 2014, 162, 445682.

6. Chen, B.; Liu, L.; Zhu, X.; Wang, J.; Long, Y.; Jiang, S.-P.; Xu, A.-G.; Lin, Y.-C. Nat. Prod. Res. 2015, 29, 1212-1216. doi:10.1080/14786419.2014.997232

7. Xiao, J.; Zhang, Q.; Gao, Y.-Q.; Tang, J.-J.; Zhang, A.-L.; Gao, J.-M. J. Agric. Food Chem. 2014, 62, 3584-3590. doi:10.1021/jf500054f

8. Koch, K.; Podlech, J.; Pfeiffer, E.; Metzler, M. J. Org. Chem. 2005, 70, 3275-3276. doi:10.1021/jo050075r

9. Altemöller, M.; Podlech, J.; Fenske, D. Eur. J. Org. Chem. 2006, 1678-1684. doi:10.1002/ejoc.200500904

10. Altemöller, M.; Podlech, J. Eur. J. Org. Chem. 2009, 2275-2282. doi:10.1002/ejoc.200900125

11. Altemöller, M.; Podlech, J. J. Nat. Prod. 2009, 72, 1288-1290. doi:10.1021/np900265q

12. Cudaj, J.; Podlech, J. Tetrahedron Lett. 2010, 51, 3092-3094. doi:10.1016/j.tetlet.2010.04.024

13. Cudaj, J.; Podlech, J. Synlett 2012, 23, 371-374. doi:10.1055/s-0031-1290135

14. Geiseler, O.; Podlech, J. Tetrahedron 2012, 68, 7280-7287. doi:10.1016/j.tet.2012.06.104

15. Nemecek, G.; Cudaj, J.; Podlech, J. Eur. J. Org. Chem. 2012, 3863-3870. doi:10.1002/ejoc.201200506

16. Nemecek, G.; Thomas, R.; Goesmann, H.; Feldmann, C.; Podlech, J. Eur. J. Org. Chem. 2013, 6420-6432. doi:10.1002/ejoc.201300879

17. Thomas, R.; Nemecek, G.; Podlech, J. Nat. Prod. Res. 2013, 27 , 2053-2054. doi:10.1080/14786419.2013.819509

18. Kohler, D.; Podlech, J. Eur. J. Org. Chem. 2019, 1748-1753. doi:10.1002/ejoc.201801801

19. EFSA Panel on Contaminants in the Food Chain (CONTAM). EFSA J. 2011, 9, 2407. doi:10.2903/j.efsa.2011.2407

20. Berkowitz, D. B.; Smith, M. K. J. Org. Chem. 1995, 60, 1233-1238. doi:10.1021/jo00110a029

21. Ladouceur, S.; Fortin, D.; Zysman-Colman, E. Inorg. Chem. 2010, 49, 5625-5641. doi:10.1021/ic100521t

22. Aciro, C.; Claridge, T. D. W.; Davies, S. G.; Roberts, P. M.; Russell, A. J.; Thomson, J. E. Org. Biomol. Chem. 2008, 6, 3751-3761. doi:10.1039/b808811j

23. Li, Y.; Li, A.-Y.; Li, B.-X.; Huang, J.; Zhao, L.; Wang, B.-Z.; Li, J.-W.; Zhu, X.-H.; Peng, J.; Cao, Y.; Ma, D.-G.; Roncali, J. Org. Lett. 2009, 11, 5318-5321. doi:10.1021/ol9022563

24. Wada, Y.; Matsumoto, A.; Asano, K.; Matsubara, S. RSC Adv. 2019, 9 , 31654-31658. doi:10.1039/c9ra05532k 
25. Altemöller, M.; Gehring, T.; Cudaj, J.; Podlech, J.; Goesmann, H.; Feldmann, C.; Rothenberger, A. Eur. J. Org. Chem. 2009, 2130-2140. doi:10.1002/ejoc.200801278

26. Alig, L.; Alsenz, J.; Andjelkovic, M.; Bendels, S.; Bénardeau, A.; Bleicher, K.; Bourson, A.; David-Pierson, P.; Guba, W.; Hildbrand, S.; Kube, D.; Lübbers, T.; Mayweg, A. V.; Narquizian, R.; Neidhart, W.; Nettekoven, M.; Plancher, J.-M.; Rocha, C.; Rogers-Evans, M.; Röver, S.; Schneider, G.; Taylor, S.; Waldmeier, P. J. Med. Chem. 2008, 51, 2115-2127. doi:10.1021/jm701487t

27. da Silva Pinto, A. C.; Silva, L. F. R.; Cavalcanti, B. C.; Melo, M. R. S.; Chaves, F. C. M.; Lotufo, L. V. C.; de Moraes, M. O.; de Andrade-Neto, V. F.; Tadei, W. P.; Pessoa, C. O.; Ribeiro Vieirac, P. P.; Pohlit, A. M. Eur. J. Med. Chem. 2009, 44, 2731-2735. doi:10.1016/j.ejmech.2008.10.025

\section{License and Terms}

This is an Open Access article under the terms of the Creative Commons Attribution License

(https://creativecommons.org/licenses/by/4.0). Please note that the reuse, redistribution and reproduction in particular requires that the author(s) and source are credited and that individual graphics may be subject to special legal provisions.

The license is subject to the Beilstein Journal of Organic Chemistry terms and conditions: (https://www.beilstein-journals.org/bjoc/terms)

The definitive version of this article is the electronic one which can be found at: https://doi.org/10.3762/bjoc.17.22 